\title{
PENERAPAN NILAI-NILAI PENDIDIKAN ISLAM DALAM PELAKSANAAN KURSUS PRA NIKAH UNTUK MEWUJUDKAN KELUARGA SAKINAH
}

\author{
Lutfi Kusuma Dewi 1) * \\ 1 Program Magister Interdisciplinary Islamic Studies, \\ Universitas Islam Negeri Sunan Kalijaga Yogyakarta \\ *E-mail: hananlutfi2029@gmail.com
}

\begin{abstract}
The birth of the Regulation of Dirjen Bimas Islam No. DJ. 491/11 of 2009 concerning Course for the Brides, which was then refined by the Regulation of Dirjen Bimas Islam No. DJ.II / 542 of 2013 concerning the Guidelines for Implementing the Pre-Marriage Course is a government effort in providing knowledge, understanding and skills for brides. With this provision, it is expected to be able to reduce divorce rates and anticipate other various family problems. In practice, this premarriage course program faced various obstacles so that it was considered to be less optimal. This article examines various problems that occur in the field surrounding the implementation of pre-marital courses and offered some Islamic education values as solutions. Regulations, socialization, legitimacy, and collaboration between institutions are needed so that the premarital course has a strong bargaining position and the implementation will be more optimal and functional.
\end{abstract}

Keywords: Pre-Marital Courses, Sakinah Family, Islamic Value

\begin{abstract}
Abstrak
Lahirnya Peraturan Dirjen Bimas Islam No. DJ.491/11 tahun 2009 tentang Kursus Calon Pengantin yang kemudian disempurnakan dengan Peraturan Dirjen Bimas Islam No. DJ.II/542 tahun 2013 tentang Pedoman Penyelenggaraan Kursus Pra Nikah merupakan upaya pemerintah dalam memberi bekal wawasan, pemahaman dan ketrampilan bagi calon pengantin. Dengan bekal itu diharapkan mampu menekan angka perceraian sekaligus mengantisipasi munculnya berbagai macam problem keluarga lainnya. Dalam prakteknya, program kursus pra nikah ini ternyata mengalami berbagai kendala sehingga dinilai kurang optimal. Artikel ini mengkaji berbagai persoalan yang terjadi di lapangan seputar pelaksanaan kursus pra nikah serta beberapa nilai pendidikan Islam yang ditawarkan sebagai jalan keluarnya. Dibutuhkan adanya regulasi, sosialisasi, legitimasi, dan kerja sama antar lembaga agar kursus pra nikah memiliki posisi tawar yang kuat sehingga pelaksanaannya akan lebih optimal dan fungsional.
\end{abstract}

Kata Kunci: Kursus Pra-Nikah, Keluarga Sakinah, Nilai Islam

\section{PENDAHULUAN}

Keluarga merupakan unit terkecil dari masyarakat yang menentukan kualitas suatu bangsa dan negara. Keluarga juga merupakan fondasi utama dalam membangun sistem dan tatanan sosial sehingga ketahanan keluarga merupakan basis ketahanan nasional. Dari sini dapat disimpulkan bahwa jika ingin membangun negara yang kuat, maka harus dimulai dari membangun kualitas keluarga. Keluarga yang tenteram, 
damai yang dilandasi ketaqwaan akan menjadi ladang persemaian lahirnya generasi berkualitas yang akan meneruskan cita-cita bangsa.

Dalam Islam dikenal dengan istilah keluarga sakiinah, mawaddah wa rahmah. Istilah ini diambil dari pesan QS. Ar-Ruum 30:21

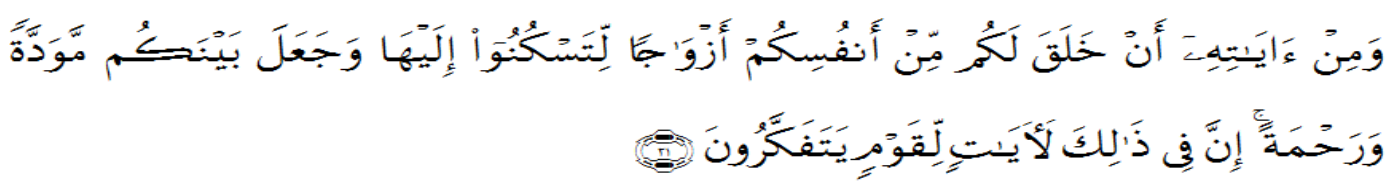

"Dan di antara tanda-tanda kekuasaan-Nya ialah Dia menciptakan untukmu isteri-isteri dari jenismu sendiri, supaya kamu cenderung dan merasa tenteram kepadanya, dan dijadikan-Nya diantaramu rasa kasih dan sayang. Sesungguhnya pada yang demikian itu benarbenar terdapat tanda-tanda bagi kaum yang berfikir"

Dalam perkembangannya, kata sakiinah diadopsi kedalam Bahasa Indonesia dengan ejaan yang disesuaikan menjadi sakinah yang berarti kedamaian, ketentraman, ketenangan dan kebahagiaan. Ada banyak tafsir yang menjelaskan tentang pengertian keluarga sakinah. Sofyan S. Willis menyatakan bahwa keluarga sakinah dapat diartikan sebagai satu sistem keluarga yang berlandaskan keimanan dan ketaqwaan kepada Allah, beramal saleh untuk meningkatkan potensi semua anggota, dan beramal saleh untuk keluarga-keluarga lain di sekitarnya, serta berkomunikasi dengan cara bimbingan yang haq, kesabaran, dan penuh dengan kasih sayang (Wilis Sofyan S, 2011:170).

Khoiruddin Nasution menjelaskan, keluarga sakinah adalah keluarga yang memiliki ketenangan minimal suami, istri, dan anak-anak, bukan sakinah salah satu pihak di atas penderitaan pihak lain (Khoiruddin Nasution, 2009L 226. Dari keluarga yang sakinah inilah diharapkan akan muncul generasi qurrata a'yun yang akan menjadi pemimpin bagi orang-orang yang bertaqwa sebagaimana dinyatakan dalam QS. AlFurqan ayat 74 .

Berdasarkan uraian tersebut dapat dipahami bahwa ada misi hebat yang harus diemban oleh keluarga sakinah dengan perkawinan sebagai pintu gerbangnya. Karena itu, dalam Islam pernikahan disebut sebagai perjanjian agung. Hal tersebut terdapat juga dalam Kompilasi Hukum Islam (KHI) dimana perkawinan diartikan sebagai akad yang sangat kuat atau mitsaqan ghalidzan untuk mentaati perintah dan merupakan ibadah bagi yang melaksanakannya. Sedangkan pengertian yang lebih komplit terdapat dalam Pasal 1 UU No.1 tahun 1974 yang berbunyi: "Perkawinan adalah ikatan 
lahir batin antara seorang pria dengan seorang wanita sebagai suami isteri dengan tujuan membentuk keluarga (rumah tangga) yang bahagia dan kekal berdasarkan Ketuhanan Yang Maha Esa". Imam al-Ghazali merumuskan tujuan dan hikmah perkawinan sebagai berikut:

1. Memperoleh keturunan yang sah, yang akan melangsungkan serta mengembangkan keturunan suku-suku dan bangsa manusia (Q.S. al-Furqan: 74)

2. Memenuhi tuntutan lahiriah hidup manusia (Q.S. al-Baqarah: 187)

3. Memelihara manusia dari kejahatan dan kerusakan (Q.S. an-Nisa': 28)

4. Membentuk dan mengatur rumah tangga yang menjadi basis pertama yang besar di atas dasar cinta dan kasih sayang (Q.S. Ar-Rum: 21)

5. Meningkatkan kesungguhan dalam mencari rezeki yang halal dan memperbesar tanggung jawab (Q.S. an-Nisa': 34) (Abu Hamid al-Ghazali, 1989: 27-36)

Dapat disimpulkan bahwa perkawinan merupakan sebuah ikatan yang kuat dan suci antara dua manusia yang dilakukan atas persetujuan kedua belah pihak guna melestarikan keturunan dan membangun keluarga yang sakinah, mawaddah, dan rahmah. Oleh karena itu sangat penting untuk mempersiapkan secara terencana, matang dan bersungguh-sungguh agar dapat memegang teguh ikatan tersebut serta menjaga amanah untuk menjalankan misi keluarga sakinah atas dasar iman dan taqwa.

Saat ini masyarakat kita dihadapkan pada perubahan yang begitu cepat di segala lini kehidupan, termasuk di dalamnya kehidupan perkawinan (keluarga). Masing masing keluarga kini dihadapkan oleh berbagai situasi yang penuh ketegangan karena makin banyaknya perbedaan kepentingan, perbedaan ukuran-ukuran moral dan perbedaan gaya hidup. Kehadiran teknologi komunikasi dan transportasi menjadikan mobilitas anggota keluarga menjadi semakin mudah, luas dan cepat.

Persaingan yang semakin ketat membawa konsekuensi tuntutan kerja yang semakin berat. Berbagai informasi yang hadir menawarkan banyak hal mendorong manusia menjadi semakin konsumtif dan sibuk memenuhi tawaran-tawaran tersebut. Hal tersebut manjadikan hubungan antar keluarga menjadi semakin berjarak dan formalistik. Perubahan tersebut jika tidak segera disadari akan mengancam stabilitas hubungan keluarga. Upaya mewujudkan keluarga sakinah menjadi tantangan yang tidak mudah.

Ketidaksiapan masing-masing keluarga dalam membina keluarga sakinah dapat menimbulkan kerawanan yang berujung pada kegagalan. Kegagalan tersebut terlihat 
dari tingginya angka perceraian dan masalah lain yang mengiringinya. Badan Peradilan Agama (BADILAG) Mahkamah Agung mencatat adanya peningkatan angka perceraian terutama di daerah daerah dengan populasi penduduk besar sebagai berikut:

Tabel 1.

Angka Perceraian di Empat Provinsi di Indonesia

\begin{tabular}{|l|l|l|l|}
\hline \multicolumn{1}{|c|}{ Tahun } & \multicolumn{1}{|c|}{2013} & \multicolumn{1}{c|}{2014} & \multicolumn{1}{c|}{2015} \\
\hline Jawa Timur & 83.201 & 87.473 & 87.241 \\
\hline Jawa Tengah & 68.202 & 70.037 & 71.774 \\
\hline Jawa Barat & 62.184 & 67.129 & 70.519 \\
\hline DKI & 8.837 & 9.731 & 10.359 \\
\hline
\end{tabular}

Kegagalan membina keluarga sakinah bukan hanya berdampak pada perceraian di antara pasangan suamu istri, tetapi juga membawa dampak pada anak-anak. Anakanak yang tumbuh dalam keluarga yang tidak harmonis atau bahkan bercerai akan menjadi korban sehingga dapat terlibat dalam berbagai kenakalan anak-anak dan remaja. Sofyan menjelaskan hasil penelitiannya bahwa berbagai bentuk kenakalan remaja seperti tawuran, pencurian, pemerasan, penyalahgunaan narkoba dan lainnya lebih banyak dilakukan oleh anak-anak dan remaja yang tumbuh dalam keluarga yang tidak harmonis (Sofyan, 2008:31). Hal tersebut tentu sangat mengkhawatirkan mengingat keluarga merupakan institusi terkecil yang menentukan ketahanan negara dan masa depan bangsa.

Menghadapi situasi seperti ini calon mempelai membutuhkan antisipasi agar tidak kehilangan orientasi untuk mempertahankan sakralitas perkawinan dan tujuan luhur kehidupan berkeluarga. Bentuk antisipasi yang paling penting adalah memberi bekal wawasan, pemahaman dan ketrampilan bagi calon pengantin. Dengan bekal itu diharapkan mampu menekan angka perceraian sekaligus mengurangi persoalan yang dialami anggota keluarga baik yang bersifat fisik, moral maupun sosial.

Lahirnya Peraturan Direktur Jendral Bimbingan Masyarakat Islam Departemen Agama tentang Kursus Calon Pengantin atau Kursus Pra Nikah sebagai bekal membangun keluarga sakinah sekaligus antisipan dari berbagai persoalan keluarga menjadi tumpuan harapan bagi calon pasangan pengantin. Namun sampai saat ini, praktek pelaksanaan kursus pra nikah di Indonesia menghadapi banyak kendala. Berbagai kendala tersebut muncul mulai dari persoalan sosialisasi, regulasi, birokrasi 
sampai persoalan teknis sehingga dinilai belum efektif dan fungsional (Siti Rugaya dkk, 2013: 166-167).

Tantangan besar yang mendesak harus dihadapi saat ini dalam rangka pembekalan calon pengantin yang mampu mewujudkan amanah regenerasi serta tanggap menghadapi situasi adalah menyiapkan kursus pra-nikah yang berkualitas dan efektif baik dari sisi format dalam pelaksanaanya. Tulisan ini akan membahas tentang berbagai persoalan yang muncul terkait pelaksanaaan kursus pra-nikah serta berbagai solusi alternatif yang memungkinkan untuk dilakukan demi terwujudnya kursus pra-nikah yang lebih optimal dan berdayaguna.

\section{METODE}

Penelitian ini adalah penelitian kualitatif yang bersifat studi pustaka yang menggunakan buku-buku dan literatur-literatur lainnya sebagai objek utama. Jenis penelitian yang digunakan adalah kualitatif, yaitu penelitian yang menghasilkan informasi berupa catatan dan data deskriptif yang terdapat di dalam teks yang diteliti. Dengan metode tersebut dapat memberikan kajian berbagai persoalan yang terjadi di lapangan seputar pelaksanaan kursus pra nikah serta beberapa nilai pendidikan Islam yang ditawarkan sebagai jalan keluarnya.

\section{PEMBAHASAN}

Kursus pra nikah merupakan bimbingan keluarga yang diberikan sebelum calon mempelai melangsungkan perkawinan. Kursus pra nikah di Indonesia dilaksanakan berdasarkan Peraturan Direktur Jendral Bimbingan Masyarakat Islam Departemen Agama DJ.II/PW.01/1997/2009 tentang Kursus Calon Pengantin yang kemudian disempurnakan dengan Peraturan Dirjen Bimas Islam No. DJ.II/542 tahun 2013 tentang Pedoman Penyelenggaraan Kursus Pra Nikah. Dalam surat disebutkan bahwa kursus calon pengantin dilaksnakan dalam rangka memimalisir tingginya angka perselisihan, perceraian dan kekerasan dalam rumah tangga yang disebabkan rendahnya pengetahua dan pemahaman tentang kehidupan berumah tangga.

Dengan latar belakang tersebut, kursus pra nikah dimaksudkan untuk pemberian bekal pengetahuan, pemahaman dan ketrampilan dalam waktu singkat tentang kehidupan rumah tangga. Berdasarkan peraturan tersebut, kursus calon pengatin dilaksanakan sekurang-kurangnya 24 jam pelajaran dengan materi meliputi:

1. Tatacara dan prosedur perkawinan 
2. Pengetahuan agama

3. Peraturan perundangan di bidang perkawinan dan keuarga

4. Hak dan kewajiban suami istri

5. Kesehatan reproduksi

6. Manajemen keluarga

7. Psikologi perkawinan dan keluarga (Pasal 3)

Penyelenggara kursus pra nikah adalah Badan Penasihatan, Pembinaan dan Pelestarian Perkawinan (BP4) atau lembaga lain yang mendapatkan akreditasi dari Departemen Agama. Bagi peserta yang telah mengikuti proses kursus calon pengantin akan mendapatkan sertifikat sebagai tanda bukti kelulusan. Sertifikat kelulusan tersebut menjadi syarat pendaftaran perkawinan. (Pasal 4)

Selanjutnya Kementerian Agama melalui Direktur Jendral Bimbingan Masyarakat Islam mengeluarka Peraturan Direktur Jendral Bimbingan Masyarakat Islam No : DJ.II/542 tahun 2013 tentang Pedoman Penyelenggaraan Kursus Pra Nikah. Dalam Peraturan Dirjen ini sudah disebutkan bahwa pembiayaan dapat bersumber dari APBN dan APBD. (Pasal 5)

Proses Kursus Pra Nikah dilaksanakan sekurangnya selama 24 jam pelajaran selama 3 hari atau lebih dengan mengacu pada jumlah jam pelajaran. Sebagai perbandingan dalam Perdirjen tersebut dibandingkan kegiatan serupa di Negara Malasyia dan Singapura. Majelis Ulama Islam Singapura menyelenggarakan kursus selama 8 kali pertemuan dalam jangka waktu 3 bulan. Sedangkan jabatan Kemajuan Islam Malasyia melaksanakan kurus pra nikah dalam 8 - 10 pertemuan dalam jangka waktu 3 bulan (Zakyyah Iskandar, 2017:93-94).

Dalam Pedoman Kursus Pra Nikah yang merupakan lampiran Peraturan Direktur Jenderal Bimbingan Masyarakat Islam telah ditetapkan kurikulum dan silabus Kursus Pra Nikah yang membagi materi kursus menjadi Kelompok Dasar, Kelompok Inti dan Kelompok Penunjang sebagai berikut:

Tabel 2.

Kurikulum dan Silabus Kursus Pra Nikah

\begin{tabular}{|c|l|l|c|}
\hline No & Materi Diklat & Uraian Materi & JPL \\
\hline A & Kelompok Dasar & & \\
\hline 1 & $\begin{array}{l}\text { Kebijakan Kementerian Agama tentang } \\
\text { Pembinaan Keluarga Sakinah }\end{array}$ & & 1 \\
\hline
\end{tabular}




\begin{tabular}{|c|c|c|c|}
\hline 2 & $\begin{array}{l}\text { Kebijakan Ditjen Bimas Islam tentang } \\
\text { Pelaksanaan Kursus Pra Nikah }\end{array}$ & & 1 \\
\hline 3 & $\begin{array}{l}\text { UU Perkawinan dan Kompilasi Hukum } \\
\text { Islam }\end{array}$ & $\begin{array}{l}\text { - Konsep perkawinan } \\
\text { - Azas perkawinan } \\
\text { - Pembatasan poligami } \\
\text { - Batasan usia nikah } \\
\text { - Pembatalan perkawinan } \\
\text { - Perjanjian perkawinan } \\
\text { - Harta bersama } \\
\text { - Hak dan kewajiban } \\
\text { - Masalah status anak } \\
\text { - Perkawinan campuran }\end{array}$ & 1 \\
\hline 4 & UU Kekerasan Dalam Rumah Tangga & $\begin{array}{l}\text { - Pengertian KDRT } \\
\text { - Bentuk-bentuk KDRT } \\
\text { - Faktor-faktor Penyebab KDRT } \\
\text { - Dampak KDRT } \\
\text { - Aturan Hukum } \\
\text { - Tanggungjawab Pemerintah } \\
\text { dan } \\
\text { keluarga }\end{array}$ & 1 \\
\hline 5 & UU Perlindungan Anak & $\begin{array}{l}\text { - Pengertian anak } \\
\text { - Hak anak } \\
\text { - Kedudukan anak dalam Islam }\end{array}$ & 1 \\
\hline 6 & Hukum Munakahat & $\begin{array}{l}\text { Menjelaskan Konsep dasar } \\
\text { perkawinan } \\
\text { Menjelaskan tujuan dan hikmah } \\
\text { perkawinan } \\
\text { Menjelaskan syarat dan rukun } \\
\text { nikah } \\
\text { Menjelaskan akad nikah dan Ijab } \\
\text { kabul } \\
\text { Menjelaskan Hak dan kewajiban } \\
\text { suami isteri }\end{array}$ & 2 \\
\hline
\end{tabular}




\begin{tabular}{|c|c|c|c|}
\hline & & $\begin{array}{l}\text { Menjelaskan mu'asarah bil } \\
\text { ma'ruf } \\
\text { Menjelaskan adab nikah } \\
\text { Menjelaskan Hak \& kewajiban } \\
\text { orang tua terhadap anak }\end{array}$ & \\
\hline $\mathrm{B}$ & Kelompok Inti & & \\
\hline 1 & Pelaksanaan fungsi-fungsi keluarga & $\begin{array}{l}\text { Fungsi Agama } \\
\text { Fungsi Reproduksi } \\
\text { Fungsi Kasih Sayang dan Afeksi } \\
\text { Fungsi Perlindungan } \\
\text { Fungsi pendidikan \& sosialisasi } \\
\text { nilai } \\
\text { Fungsi ekonomi } \\
\text { Fungsi social budaya }\end{array}$ & 2 \\
\hline 2 & Merawat Cinta Kasih dalam Keluarga & $\begin{array}{l}\text { Nilai-nilai dalam keluarga untuk } \\
\text { me-wujudkan mu'asyarah bil } \\
\text { ma'ruf } \\
\text { Formula sukses dalam } \\
\text { mengelola } \\
\text { perkawinan dan keluarga } \\
\text { Komunikasi efektif dalam } \\
\text { pengelolaan hubungan keluarga }\end{array}$ & 2 \\
\hline 3 & Manajemen Konflik dalam Keluarga & $\begin{array}{l}\text { Faktor penyebab konflik } \\
\text { Tanda-tanda perkawinan dalam } \\
\text { bahaya } \\
\text { Solusi atau cara mengatasi } \\
\text { konflik }\end{array}$ & 2 \\
\hline 4 & Psikologi Perkawinan dan Keluarga & $\begin{array}{l}\text { Pengertian/Deskripsi } \\
\text { Upaya mencapai keluarga } \\
\text { sakinah } \\
\text { Membina hubungan dalam } \\
\text { keluarga }\end{array}$ & 2 \\
\hline
\end{tabular}




\begin{tabular}{|c|l|l|c|}
\hline C & Kelompok Penunjang & & \\
\hline 1 & Pendekatan Andragodi & & 1 \\
\hline 2 & $\begin{array}{l}\text { Penyusunan Satuan Acara } \\
\text { Pembelajaran }\end{array}$ & & 1 \\
\hline 3 & Pre-Test dan Post-Test & & 1 \\
\hline 4 & Penutup & & 1 \\
\hline
\end{tabular}

\section{A. Persoalan Pelaksanaan Kursus Pra Nikah}

Kursus Pra Nikah merupakan kegiatan yang bukan hanya penting tetapi juga punya nilai strategis dalam rangka mewujudkan keluarga sakinah, mengurangi angka penceraian dan menurunkan kenakalan remaja sebagai akibat kegagalan mewujudkan keluarga sakinah. Pelaksanaan Kursus Pra Nikah di Indonesia saat ini masih mengalami berbagai kendala. Berbagai persoalan yang muncul adalah sebagai berikut:

Pertama, Posisi kursus pra nikah secara hukum kurang kuat. Kalau kursus pra nikah ini ditempatkan sebagai penjabaran atau tindak lanjut dari UU No 1 Tahun 1074 tentang Perkawinan maka seharusnya ada Peraturan Pemerintah (PP) atau setidaknya Peraturan Menteri Agama (Permen) yang mengatur tentang kursus pra nikah sebagai salah satu persyaratan melakukan perkawinan. Kenyataanya dasar hukum pelaksanaan kursus pra nikah hanya Peraturan Dirjen.

Dalam Peraturan Dirjen Bimbingan Masyarakat Islam tahun 2009 disebutkan bahwa peserta yang lulus kursus calon pengantin yang dibuktikan dengan sertifikast kursus merupakan persyaratan melakukan perkawinan. Namun dalam praktek di lapangan, calon pengantin yang tanpa sertifikat tetap boleh mendaftar. Demikian juga pada Peraturan Dirjen Bimas Islam tahun 2013 disebutkan bahwa sertifikat kursus pra nikah dinyatakan sebagai syarat kelengkapan pencatatan perkawinan. Dengan demikian sertifikat kursus pra nikah tidak mempengaruhi pasangan untuk mendaftarkan dan melaksanakan perkawinan.

Kurang jelasnya posisi tawar sertifikat kursus pra nikah bisa berdampak pada timbulnya berbagai kendala teknis dalam pelaksanaan kursus pra nikah. Kendala tersebut misalnya dalam proses sosialisasi, durasi waktu. Karena sertifikat 
pra nikah hanya sebagai perlengkapan persyaratan administrasi, maka keberadaan kursus pra nikah dianggap tidak terlalu penting.

Masih banyak masyarakat yang baru mengetahui persyaratan kursus calon pengantin ketika mereka mengurus syarat pernikahan di KUA. Akibatnya kendala teknis tentang jadwal pelaksanaan kursus sering terjadi. Calon pengantin kesulitan menjadwalkan mengikuti kursus karena adanya kesibukan yang meningkat menjelang perkawinan. Hal tersebut memunculkan kendala lain yakni masalah durasi waktu, materi dan metode.

Karena adanya kesibukan yang meningkat menjelang perkawinan, durasi waktu yang menurut Peraturan Dirjen Bimbingan Masyarakat Islam dilaksanakan selama 3 hari dengan 24 jam pelajaran, dalam kenyataannya kegiatan kursus pra nikah dilaksanakan dengan durasi satu hari, bahkan beberapa jam saja sebagaimana disampaikan dalam penelitian Siti Rugaya dan Muhammad Sudirman berdasarakan penelitiannya, bahwa pelaksanaan kursus pra nikah di wilyah Makasar berlangsung hanya 2-3 jam melalui metode ceramah. Kegiatannya lebih bersifat informal, bahkan ada yang hanya ngobrol santai dengan calon pengantin dirasa sudah cukup. Dengan pelaksaaan yang tidak sesuai dengan ketentuan tersebut, calon pengantin tetap dianggap memenuhi persyaratan untuk melaksanakan perkawinan dan mendapatkan buku nikah (Siti Rugaya dan Muhammad Sudirman, 2016:160).

Dari sisi cakupan materi, Peraturan Dirjen Bimas Islam tahun 2013 memang terlampir silabus yang menjadi panduan sebagaimana tertera di atas, namun silabus tersebut belum tersusun sempurna. Jumlah materi bahasan yang begitu banyak tidak sepadan dengan jumlah jam yang tersedia (hanya 24 JPL). Selain materi tersebut terlalu padat, dalam silabus tersebut belum mengakomodir materi seperti pemahaman seputar kesehatan reproduksi.

Kedua, masalah penyelenggaraan kursus oleh BP4 sebagai satu-satunya lembaga. Demikian juga sebagai nara sumber yang dalam ketentuan melibatkan pihak luar sesuai dengan keahlian yang relevan juga belum berjalan. Pemateri kursus lebih banyak dilakukan oleh pengurus BP4 atau pegawai KUA setempat. (Siti Rugaya dkk, 2016: 158)

Ketiga, kendala teknis yang utama dari pelaksanaan kursus calon pengantin adalah tentang pendanaan. Sesuai peraturan pelaksanaan kursus pra nikah didanai oleh APBN dan APBD, namun kenyataannya pendanaan kursus hanya dari APBN. 
Namun sumber dana dari APBN tersebut jumahnya sangat jauh dari memadai untuk menyelenggarakan kursus selama 3 hari (Elsi Nurfajri, 2017:74). Kendala tidak adanya sumber dana APBD adalah karena dalam UU No 32 Tahun Pemerintah Daerah, urusan agama merupakan salah satu yang tidak masuk urusan yang kewenangannya dilimpahkan kepada daerah, selain hukum, hubungan luar negeri, dan keuangan.

Dengan kondisi demikian akan sulit bagi pemda propinsi atau kabupaten/kota untuk menganggarkan dalam APBD. Karena pemerintah Propinsi maupun kabupaten/kota tidak memiliki badan, dinas atau kantor yang mengurusi tentang agama dalam hal ini perkawinan. Urusan perrkawinan diurus oleh Kanwil Kemenag Propinsi dan Kantor Kemenag kabupaten/kota sampai dengan KUA yang semuanya berada dalam struktur kementrian agama sehingga Pemda Propinsi dan Kabupaten/kota tidak bisa mengalokasikan anggaran.

\section{B. Solusi Bagi Peningkatan Kualitas Kursus Pra Nikah}

Mengingat penting dan strategisnya kegiatan pra nikah dalam upaya mewujudkan keluarga sakinah serta sebagai antisipan terhadap berbagai persoalan keluarga, maka perlu dilakukan upaya menyeluruh, mulai dari hal yang mendasar sampai dengan hal yang bersifat teknis. Upaya yang harus dilakukan antara lain:

1. Agar posisi hukum kursus pra nikah ini lebih kuat secara hukum (fiqh), perlu peran Majelis Ulama Indonesia (MUI) untuk melakukan kajian tentang hukumnya mengikuti kursus pra nikah sebelum melakukan perkawinan. Dengan demikian, keberadaan sertifikat kursus pra nikah memiliki posisi tawar yang lebih baik. Kajian ini menemukan urgensinya ketika dihadapkan pada tingginya angka perceraian dan kompleksitas persoalan mengiringinya yang menunjukkan ketidaksiapan keluarga menghadapi realitas kehidupan sosial di era global dengan dinamikanya yang begitu cepat. Banyak sekali pesan ayatayat Al Qur'an dan Hadis nabi yang menjelaskan perlunya bekal (al ba'ah) bagi pasangan yang akan melaksanakan pernikahan.

Ada baiknya kita berkaca dari proses penyelenggaraan haji yang juga dikelola oleh kementerian agama yang selama ini berlangsung dengan rapi dan tertib. Dengan sederet peraturan pemerintah yang ada sekarang ini, para calon jamaah haji dengan tertib mengikuti berbagai prosedur cek kesehatan yang 
harus (wajib) dijalaninya berbulan -bulan dengan biaya mandiri untuk mendapatkan rekomendasi kelayakan (istitho'ah).

Selain itu calon jamaah haji juga rela antri bertahun tahun dan rela mengikuti persiapan manasik hampir 6 bulan lamanya untuk sebuah perjalanan haji selama kurang lebih satu bulan. Ternyata berbagai kebijakan kementerian agama yang dikerja samakan antar lembaga seperti: dinas kesehatan, KBIH, Kantor Imigrasi, dan sebagainya semua berjalan sesuai prosedur dengan diikuti evaluasi dan perbaikan tiap tahunnya.

Bagaimana dengan janji suci perkawinan (mistaqon ghalizha) yang harus dipegang teguh seumur hidup sebagai amanah dari Tuhan? Tentu hal ini akan menjadi kajian menarik yang perlu dilakukan oleh MUI dan organisasi keagamaan seperti NU, Muhammadiyah dan lain-lain. Dengan adanya pendapat hukum dari MUI atau ormasi Islam lainnya akan menjadi landasan bagi pelaksanaan kursus pra nikah.

Adanya kejelasan posisi tawar sertifikat kursus pra nikah menjadikan problem sosialisasi menjadi lebih mudah. Kementerian agama bisa membuat surat edaran yang bisa diedarkan melalui berbagai media sosial, melalui para ustad di pengajian, melalui buku pelajaran, diselipkan dalam salah satu program tayangan di televisi, leaflet, pamflet dan sebagainya.

Sebelum kajian hukum oleh MUI dan ormas Islam lainnya perlu diambil langkah sementara yaitu kursus pra nikah bukan menjadi syarat perkawinan tetapi menjadi syarat mendapat buku nikah. Pengantin yang sudah menikah namun belum lulus kursus calon pengantin maka buku nikahnya belum diberikan kepada yang bersangkutan dan hanya mendapatkan foto kopi sampai memenuhi persyaratan.

2. Terkait penyelenggara kursus, Kementerian Agama dalam hal ini BP4 dapat bekerja sama dengan ormas Islam atau perguruan tinggi Islam yang memenuhi syarat akreditasi sebagai penyelenggara kursus pra nikah, atau narasumber yang bersertifikasi untuk memberikan materi kursus pra nikah. Dengan kerja sama tersebut kursus pra nikah dapat menjadi program kaderisasi ormas Islam terutama ormas kepemudiaan seperti IPM, IMM, HMI, PMII, IPPNU, Fatayat, NA dan lain sebagainya. Ormas kepemudaan tersebut dapat menyelenggarakan kursus calon pengantin bagi kader-kadernya, meskipun mereka belum 
menentukan waktu perkawinan. Kursus juga dapat dilakukan oleh perguruan tinggi Islam kepada mashasiswanya baik yang sudah punya pasangan dan menentukan waktu perkawinan atau belum. Jika materi dan metode yang disajikan menarik, apalagi di sebuah tempat yang bernilai rekreatif tentu saja akan menarik minat masyarakat dan memiliki nilai jual. Mereka tidak akan segan segan merogoh dana sendiri untuk keperluan ini.

Meski demikian perlu juga lembaga kursus yang mampu mengakomodir calon pasangan yang memiliki keterbatasan biaya. Dengan kerja sama (sponsor) dari berbagai instansi swasta seperti catering, salon, Wedding orgenaizer, tentu biaya akan lebih ringan. Hal ini sekaligus menjadi bagian dari solusi masalah pendanaan. Peserta terbuka untuk siapa saja yang membutuhkan. Mereka tidak harus pasangan yang hendak menikah, tetapi siapa saja yang sudah memasuki usia dewasa dan berencana untuk menikah.

Dengan sertifikat yang diperoleh dari kursus tersebut dapat menjadi syarat jika nanti mereka hendak melangsungkan perkawinan. Memang perlu ada tambahan ketika menjelang perkawinan, tinggal dilakukan review dan penyegaran bersama calon pasangannya. Kegiatan review ini mungkin cukup dilakukan satu kali pertemuan selama 1-2 jam karena materi kursus yang lengkap sudah dilakukan sebelumnya.

3. Untuk mengatasi soal pembiayaan, dibutuhkan adanya regulasi sebagai pijakan lebih lanjut dalam pelaksanaan Peraturan Direktur Jendral Bimbingan Masyarakat Islam No : DJ.II/542 tahun 2013. Kementrian agama harus mendorong munculnya Peraturan Pemerintah (PP) yang bisa menjadi landasan hukum bagi kegiatan kursus pra nikah. Dengan adanya PP akan mengikat kementrian dan lembaga lain untuk mendukung program ini baik secara kebijakan maupun pendanaan.

Alternatif lainnya adalah mendorong Surat Keputusan Bersama (SKB) Menteri Agama dengan kementrian lain yang terkait seperti Menteri Dalam Negeri, Menteri Kesehatan, Menteri PAN RB, Menteri Pemberdayaan Perempuan dan lain-lain. Dengan adanya SKB tersebut akan dapat mengikat pemda propinsi dan pemda untuk mendukung secara kebijakan maupun pendanaan. Jika landasan hukumnya sudah jelas, dan didukung oleh kebijakan 
oleh pemda propinsi, maka akan lebih mudah dalam penggalangan dana. Bahkan jika perlu calon pengantin mengeluarkan dana secara mandiri.

\section{Nilai Pendidikan Islam yang Perlu Diterapkan dalam Kursus Pra Nikah}

Agar pernikahan itu langgeng serta diwarnai oleh sakinah, agama menekankan sekian banyak hal, Faktor-faktor yang diperlukan dalam membentuk keluarga sakinah menurut M. Quraish shihab antara lain:

1. Kesetaraan

Kesetaraan ini mencakup banyak aspek, seperti kesetaraan dalam kemanusiaan. Tidak ada perbedaan dari segi asal kejadian antara lelaki dan perempuan. Sekian kali kitab suci al-qur'an menegaskan bahwa ba'dhukum min $b a^{\prime} d h$ (sebagian kamu dari sebagian yang lain). Ini adalah satu istilah yang digunakan untuk menunjukan kesetaraan atau kebersamaan dan kemitraan sekaligus menunjukan bahwa lelaki sendiri atau suami sendiri, belumlah sempurna ia baru sebagian demikian juga perempuan, sebelum menyatu dengan pasangannya juga baru sebagian. Mereka baru sempurna bila menyatu dan bekerja sama.

Percampuran yang direstui Allah terjadi berkat kerja sama dan kerelaan masing-masing untuk membuka rahasia yang terdalam, dan ini tidak mungkin terjadi tanpa adanya kemitraan antara keduanya (Shihab, 2006: 147-149). Dahulu, ulama-ulama menekankan kaffah dari segi keturunan dan agama. Namun, kini kafaah dan kesetaraan lebih ditekankan di samping pada pandangan hidup atau agam, juga pada budaya, tingkat pendidikan serta usia.

2. Musyawarah

Jika islam bertujuan membangun masyarakat yang kuat dan rekat, disini keluarga memiliki peran besar dalam mewujudkan tujuan ini karena secara teknis keluarga membentuk dan mengembangkan hubungan sosial baru melalui garis nasab pernikahan. Manusia hidup dalam masyarakat ia akan terikat kepada norma-norma yang ada dalam masyarakat. Dalam kaitan dengan hal ini maka perkawinan merupakan suatu hal yang erat kaitannya dengan halhal tersebut diatas dengan perkawinan, hubungan suami istri diharapkan akan dapat dipenuhi secara optimal (Walgito, 2004: 22) 
Pernikahan meraih sukses jika kedua pasangan memiliki kesadaran bahwa hidup bersama adalah take and give, kaki harus silih berganti di depan, dan bahwa hidup berumah tangga walaupun disertai dengan aneka masalah dan kesulitan jauh lebih biak daripada hidup sendiri-sendiri. Aneka keinginan atau problem yang dihadapi, harus diselesaikan dengan musyawarah atas dasar kesetaraan kedua belah pihak. Musyawarah tidak dapat dilaksanakan dalam situasi ketika seseorang merasa lebih unggul daripada yang lain.

Pada saat bermusyawarah atau berkomunikasi, banyak sekali tuntunan dan tata cara yang diajarkan agama, mulai dari sikap batin dan kesediaan memberi maaf, kelemahlembutan dan kehalusan kata-kata, sampai pada ketekunan mendengarkan mitra musyawarah atau diskusi.

Masing-masing juga harus mampu mengetahui kebutuhan dan pandangannya serta memiliki ketrampilan mengungkapkannya, disamping mampu pula mendengar secara aktif pandangaan mitranya, sehingga tidak tergesa-gesa mengambil kesimpulan. Dalam hal musyawarah tidak mepertemukan pandangan, salah seorang harus mampu menyatakan bahwa, "boleh jadi engkau yang benar". Kalimat ini tidak kurang mesranya dari kalimat, "aku cinta atau aku bangga padamu". Kalimat itulah yang otomatis lagi penuh kesadaran akan tercetus selama mawaddah dan rahmah menghisai jiwa mereka (Shihab, 2006: 153).

3. Kesadaran akan kebutuhan pasangan

Di tengah kelapangan iklim keluarga, masing-masing pasangan suami istri bisa menemukan rasa kasih, cinta, sayang dan simpati yang tidak akan bisa mereka cicipi di tempat lain. Ketenangan jiwa dan kasih sayang yang dirasakan manusia terhadap pasangannya merupakan salah satu tuntutan psikologis yang tidak pernah lepas dari setiap diri manusia dan tidak ditemukan selain dalam institusi pernikahan. Ini merupakan jenis ketenangan yang berbeda dengan ketenangan lain. Ketenangan ini adalah ketenangan ruh pasangannya, sehingga seolah-olah ruh keduanya menyatu dan hati mereka pun berpadu menjadi satu ruh dan satu hati.

Kitab suci al-Qur'an menggarisbawahi bahwa suami maupun istri adalah pakaian untuk pasangannya. Kiasan tersebut menggarisbawahi sekian banyak hal yang harus disadari oleh suami istri guna terciptanya keluarga sakinah. 
Kalau dalam kehidupan normal sehari-hari seorang tidak dapat hidup tanpa pakaian, demikian juga keberpasangan tidak dapat dihindari dalam kehidupan normal manusia dewasa. Kalau pakaian berfungsi menutup aurat dan kekurangan jasmani manusia, demikian pula pasangan suami istri harus saling melengkapi menutupi kekurangan masing-masing.

Kalau pakaian merupakan hiasan bagi pemakainya, suami adalah hiasan bagi istrinya, demikian pula sebaliknya. Kalau pakaian mampu melindungi manusia dari sengatan panas dan dingin, suami terhadap istrinya dan istri terhadp suaminya harus pula mampu melindungi pasangannya dari krisis dan kesulitan yang mereka hadapi. Walhasil, suami istri saling membutuhkan. Kebutuhan tersebut banyak dan beraneka ragam tidak hanya dalam bidang jasmani atau seks, tetapi juga ruhani sedemikian banyak hingga dia tidak putusputusnya. Begitu kebutuhan tersebut tidak dirasakan lagi, ketika itu pula cinta memudar dan pernikahan goyah (Shihab, 2006: 154).

Tanpa kesadaran akan kebutuhan-kebutuhan tersebut, dan tanpa memfungsikan pernikahan seperti makna-makna tersebut, kehidupan rumah tangga tidak akan menggapai sakinah, dan juga berarti bahwa agama belum berfungsi dengan baik dalam kehidupan rumah tangga.

\section{SIMPULAN DAN SARAN}

\section{A. Simpulan}

Keberadaan kursus pra nikah dalam rangka mewujudkan keluarga sakinah sekaligus sebagai antisipan terhadap berbagai persoalan keluarga merupakan kebutuhan yang penting dan mendesak. Peraturan Dirjen Bimas Islam No. DJ.491/11 tahun 2009 tentang Kursus Calon Pengantin yang kemudian disempurnakan dengan Peraturan Dirjen Bimas Islam No. DJ.II/542 tahun 2013 tentang Pedoman Penyelenggaraan Kursus Pra Nikah membutuhkan beberapa regulasi lanjutan agar dalam pelaksanaannya berjalan optimal sesuai yang diharapkan.

\section{B. Saran}

Dalam pelaksanaan kursus pra nikah perlu diterapkan beberapa nilai pendidikan Islam, yaitu:

1. Kesetaraan dengan pasangan 
2. Musyawarah dalam keluarga

3. Kesadaran akan kebutuhan pasangan

Selain itu, upaya mengoptimalkan pelaksanaan kurus pra nikah juga perlu dilakukan melalui :

1. Perlu peran Majelis Ulama Indonesia (MUI) untuk melakukan kajian hukum mengikuti kursus pra nikah hal ini akan menaikkan posisi tawar sertifikat kursus pra- nikah

2. Kegiatan Kursus Pra Nikah dilaksanakan tidak hanya dilakukan ketika akan menikah, tetapi dapat dilakukan jauh hari melalui kegiatan yang terintegrasi dengan kegiatan pengkaderan dan pendidikan.

3. Kementerian agam (BP4) butuh bekerja sama dengan ormas Islam atau perguruan tinggi Islam yang memenuhi syarat sebagai penyelenggara kursus pra nikah, atau narasumber yang bersertifikasi untuk memberikan materi kursus pra nikah

4. Mendorong munculnya regulasi seperti Surat Keputusan Bersama (SKB) menteri atau Peraturan Pemerintah (PP) yang bisa menjadi landasan hukum bagi kegiatan kursus pra nikah. Dengan adanya PP akan mengikat kementrian dan lembaga lain untuk mendukung program ini baik secara kebijakan maupun pendanaan.

\section{DAFTAR PUSTAKA}

Bimo, Walgito, "Pengantar Psikologi Umum”, Andi: Jakarta, 2004.

Eka Purnamasari, "Penyelenggaraan Kursus Calon Pengantin di KUA Pamulang Tangerang Seelatan”, Skripsi, Fakultas Syari'ah dan Hukum, Universitas Islam Negeri Syarif Hidayatullah, Jakarta, 2016.

Elsi Nurfajri, "Pelaksanaan Kursus Pra Nikah di BP4 Se Kota Yogyakarta", Skripsi, Fakultas Syari'ah dan Hukum Universitas Islam Negeri Sunan Kalijaga, Yogyakarta, 2017.

Zakyyah Iskandar, "Peran Kursus Pra Nikah dalam Mempersiapkan Pasangan Suami Istri Menuju Keluarga Sakinah", Al Ikhwat, Vol 101 Juni 2017.

Dzulfa Arifah Ahdiyani, "Preaktek Kursus Calon Pengantin Sebagai Upaya KUA Kecamatan Secang Kabupaten Magelang dalam Meminimalisir Angka Perceraan", Skripsi, Fakultas Syariah dan Hukum Islam Universitas Negeri Walisongo, Semarang, 2017. 
Keluarga Sakinah, Asy-Syir'ah Jurnal Ilmu Syariah dan Hukum, Vol.46, No.1, JanuariJuni 2012.

Khoiruddin Nasution, Hukum Perdata (Keluarga) Islam Indonesia dan Perbandingan Hukum Perkawinan di Dunia Muslim, (Yogyakarta: Academia, 2009)..

Khoiruddin, Arah Membangun Hukum Keluarga Islam Indonesia: Pendekatan Integratif dan Interkonektif dalam Membangun Keluarga Sakinah, Asy-Syir'ah Jurnal Ilmu Syariah dan Hukum, Vol.46, No.1, Januari-Juni 2012.

Mahtuf Ahnan dan Maria Ulfa, Risalah Fiqh Wanita, Pedoman Ibadah Kaum Wanita Muslimah dengan Berbagai Permasalahannya, (Surabaya: Terbit Terang, ttt).

Sofyan, Remaja dan MaslaahannyaMengupas sebagai Kenakalan Remaja seperti Narkoba Sex Bebas dan Pencegahannya,(IKAPI Jawa Barat, 2008).

Sayyid Sabiq, Fiqh al-Sunnah, Jakarta: Cakrawala Publishing, 2009.

Shihab, Quraisy, Tafsir Al-Misbah: Pesan, Kesan dan Keserasian al-Qur'an, Jakarta: Lentera Hati, 2006.

Willis, Sofyan S, Konseling Keluarga (Family Counseling), Bandung: Alfabeta, 2011.

Peraturan Direktur Jendral Bimbingan Masyarakat Islam Departemen Agama DJ.II/PW.01/1997/2009 tentang Kursus Calon Pengantin.

Peraturan Direktur Jenderal Bimbingan Masyarakat Islam No. DJ.II/542 tahun 2013 tentang Pedoman Penyelenggaraan Kursus Pra Nikah.

Undang-Undang No 1 Tahun 1974 Tentang Perkawinan.

Undang-Undang No 23 Tahun 2016 tentang Pemerintah Daerah.

http://www.hidayatullah.com/berita/nasional/read/2014/09/14/29443/angkaperceraian-meningkat-menteriagama-sarankan-ikuti-seminar-pra-nikah.html diakses pada tanggal 01 Oktober 2015 